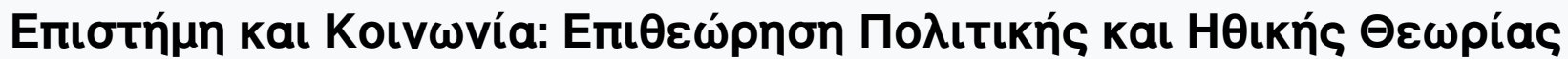

Tó 10 (2003)

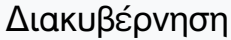

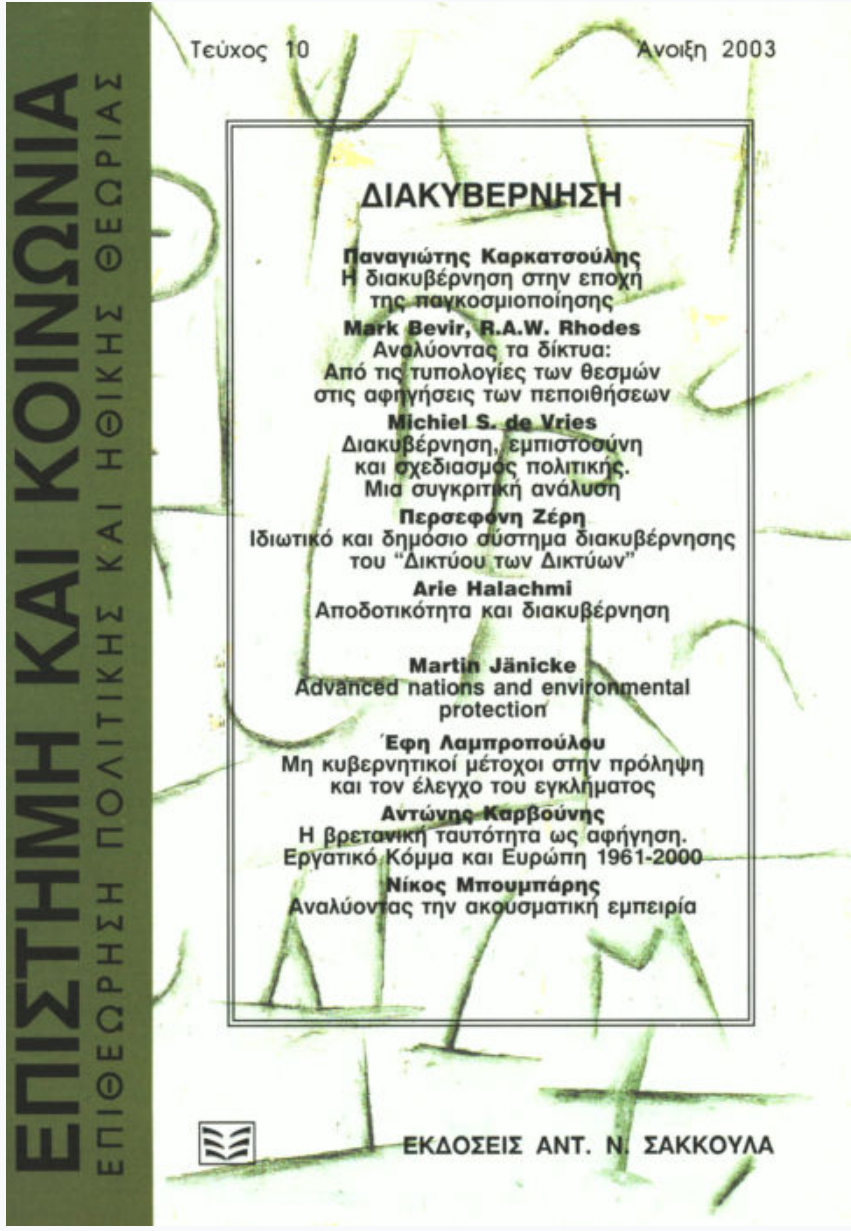

Advanced nations and environmental protection: the challenge of globalisation

Martin Jänicke

doi: $10.12681 /$ sas.702

Copyright @ 2015, Martin Jänicke

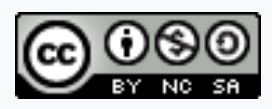

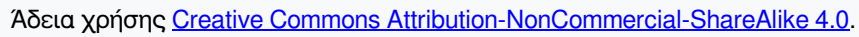

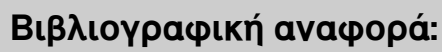

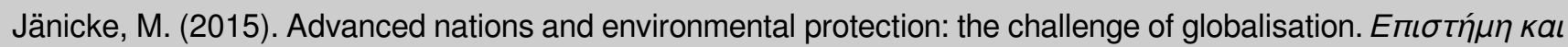

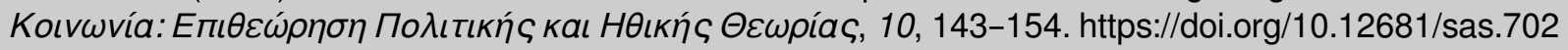




\section{Advanced nations and environmental protection: The challenge of globalisation}

\section{Martin Jänicke*}

Over the last few years, we have witnessed more and more fears that the nation state and its ability to set demanding standards in fields like environmental policy has diminished in the context of globalisation. There is, on the other hand, the hopeful prognosis of neo-classical economists that the same globalisation will be connected with deregulation and fundamental reduction of the role of government. Neither the fear nor the hope of a withering away of the nation state in times of globalisation are supported by empirical research. States in concert have expanded and co-ordinated their regulatory powers. And it is only the nation state, the guarantor of diverse societal interests that has the competence, the resources, the power and legitimacy to regulate the actions of disparate actors who might otherwise destroy shared environmental resources. There is remarkable potential, at least in the advanced OECD countries, to promote change through the adoption of a pioneering policy, the stimulation of international competition and the diffusion of best practice. This potential of the highly advanced countries may be seen as a moral obligation to assume a higher responsibility for global environmental development. The advanced nations cannot hide behind the fictitious monster of globalisation, seemingly legitimising any kind of inactivity. On the contrary, it is their obligation to provide the world with better 'demonstration effects', with a better model of production and consumption, overcoming the resource and environment intensive model of the past.

\footnotetext{
* Professor of Political Sciences, Freie Universität Berlin.
} 
The subject is still highly relevant, since the debate has taught us valuable lessons regarding the role of the nation state in the context of globalisation.

I would like to present ten theses regarding the role of the nation state in global environmental policy. My basis is mainly composed of cross-national studies, partly conducted by the Environmental Policy Research Unit of the Free University of Berlin.

\section{1) The open ('globalised') national economy needs and is charac- terised by strong government, both in size and scope}

This is contrary to the thinking of many neo-classical economists. There are cross- national studies showing that public expenditures in open economies in the OECD tend to be relatively higher (Cameron 1978, Garret 1998, Bernauer 2000). But it seems plausible to assume both a larger size and a larger scope of government activities in countries being highly integrated into the international economy. Open economies need:

- a well-developed infrastructure for successful international competition, that translates into more money and more public activities in fields such as education, $\mathrm{R} \& \mathrm{D}$ or transportation.

- the compensation of distributional and other effects of rapid structural changes connected, for example, with a low degree of protection of domestic industries.

- more regulatory activities of all kinds necessary to adapt to international developments (e.g. standards).

\section{2) The nation state is both the subject and the object of global envi- ronmental policy learning and lesson-drawing}

The national government is the subject of policy learning on how to solve environmental problems. At the same time, national governments are looking for best practice, observing other governments (Rose 1993, Bennett 1991, Kern et al. 2001). Successful environmental policy innovations -the introduction of new institutions, instruments, or strategies-are thereby often adopted by other governments. This improvement by imitation can be conceived as horizontal policy learning. It is an important mechanism of global environmental policy development and policy convergence. International institutions such 
as the OECD, UNEP or special regimes play an important role as policy arenas for pioneers and as agents for the diffusion of environmental policy innovations. This role seems to be more important than the creation of policy innovations by the international institutions themselves. Figure 1 shows some examples of the diffusion of environmental policy innovations -such as Environmental ministries or green plans from pioneer countries to the rest of the world. The speed of diffusion has increased in the 1990s, strongly supported by the Rio process. This may imply capacity building at the national level, even if the divergence of capacities (beneath the convergent policy patterns) remains considerably high.

Figure 1:

Global Diffusion of Environmental Policy Innovations

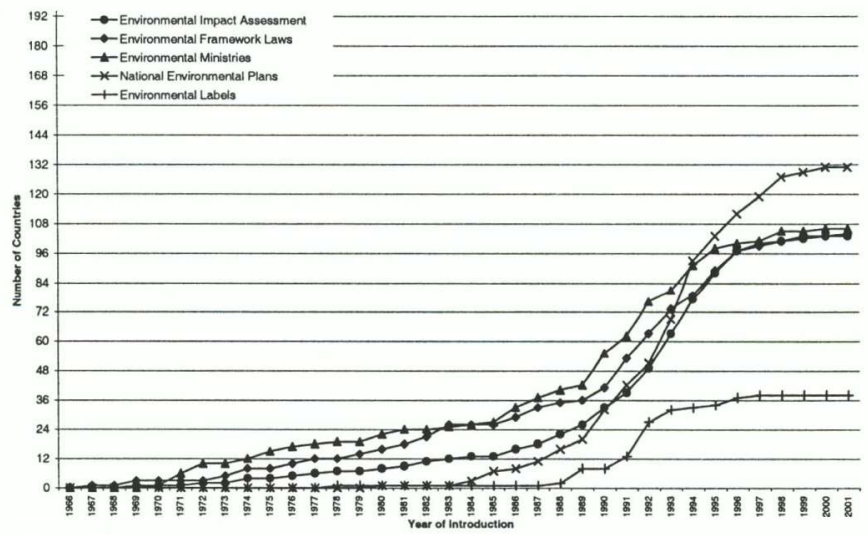

Source: Busch \& Jörgens 2002

\section{3) Policies are differently affected by globalisation}

The international pressure on wages, taxes on mobile sources and social security provisions is a stark reality in times of globalisation (Scharpf 1998). Environmental, but also health or security standards have their own (e. g. WTO) rules and their own logic in international regulatory competition. The 
reasons why environmental policy is a particular case seem to be extremely important and need special explanation:

\section{4) There is no 'race to the bottom' in environmental policy - but why?}

Several empirical cross-national studies have rejected the RTB-hypothesis (see box).

Many arguments are well-known today (Vogel 2001, Wheeler 2001, Drezner 2001):

\section{No international race to the bottom:}

- We find no race to the bottom...countries with more open trade regimes have more stringent regulations' (Eliste \& Fredricksson 1998).

- National environmental pioneer policy can create 'first-mover advantages' (Ashford 1979, Porter \& van der Linde 1995, Wallace 1995).

- Bangladesh, India, Indonesia, and Thailand 'are fast adopting industrial pollution control standards similar to those in developed countries' (Hettige et al. 1996).

- Strict environmental policy is no strong incentive to de-locate 'dirty industries' into developing countries with re-imports into rich countries (Jaffe et al. 1995, Jänicke et al. 1997).

Countries and companies that trade with countries with strict regulations tend to have stricter policies themselves (Eliste \& Fredricksson 1998, Foljanty-Jost 1997) - the largest markets are rather strictly regulated. The globalisation of environmental policy has partly changed the framework conditions of the world market (Jänicke \& Weidner 1997, Weidner \& Jänicke 2002, Vogel 2001). Regulatory competition in the environment often creates firstmover advantages for national economies. This is a part of global competition (Porter 1991, Wallace 1995) and is essential to the development of 'environmental lead markets' (Jänicke \& Jacob 2001). Strict environmental regulations (within limits) remain a possibility to protect national industries. Multinationals tend to use the same standards everywhere (Wheeler 2000). Differences in environmental standards tend to decrease; on the whole, they are less important than differences e. g. in labour costs or taxes.

I would like to add two arguments: 
- The environmental issue has become a significant dimension of general technological progress. Forty percent of all innovations in 2010 are projected to be relevant to environmental improvement (Faucheux 2000).

- The environmental issue has become important in the international competition for innovation - there is a close correlation between strict environmental regulation and competitiveness.

\section{5) Pioneer countries in environmental policy are highly competitive}

The Global Competitive Report shows a remarkably high correlation $\left(\mathrm{R}^{2}\right.$ $=0.89$ ) between ambitious environmental policy and the competitiveness of a country (Global Competitiveness Report 2000). Other studies have revealed a similar relationship (Sturm et al. 2000). Of course, this is no causal proof. The causal relation can go in both directions; also, third factors (e. g. the GNP per capita) may be important. But in light of such a correlation, no one can convincingly insist on the traditional economic argument of an immanent contradiction between competitiveness and a demanding environmental policy. The strong correlation of the 'third factor' GNP can be explained by the following formula: Highly developed countries are characterised by both high perceived environmental pressure and high capacity to react.

\section{6) Globalisation has created a policy arena for pioneer countries, at least in environmental policy}

The pioneering environmental policy of certain highly developed countries has always been possible since 1970 . The influence of small innovative countries in global policy has never before been as important as today in the field of environmental policy (Andersen \& Liefferink 1997, Jänicke \& Weidner 1997, Jänicke \& Jacob 2001). This means that political competition and the pioneer roles of countries have become relevant. But political competition needs an arena. The Johannesburg Summit may be used as an example. Here the situation has improved since the end of the Cold War (and its dichotomic policy arena). International institutions like the OECD or the UNEP, but also global networks of all kinds provide a basis for benchmarking and competition in global environmental policy. The hard core is regulatory competition giving support to domestic innovative industries or protecting the national regula- 
tory culture against pressures to adapt to policy innovation from abroad. This countervailing mechanism against the neglect of environmental considerations in the global economy may not be strong enough, but it can be improved.

\section{National Environmental Regulations and Competitiveness:}

- 'How an industry responds to environmental problems may, in fact, be a leading indicator of its overall competitiveness' (Porter \& van der Linde 1995).

- '...tough regulations will stimulate innovations, making firms generally fitter and more competitive' (Wallace 1995).

- The ecologically innovative position of Japan's main export branches 'was not brought about by ...political pressure, but rather by the...fear of decreased competitiveness in the European market' (Foljanty-Jost 1997).

- '...measures for environmental protection (that) act as trade barrier will be the international trend. Thus...Korea will...strengthen environmental policy measures...to improve the...competitiveness of Korean companies' (Korean Ministry of the Environment 1995).

\section{7) New technologies as a rule start from national 'lead markets'}

The ecological modernisation of the world market depends on national lead markets for environmental innovations (Jänicke \& Jacob 2001, Beise 2001). A lead market is 'the core of the world market where the local users are early adopters of an innovation on an international scale' (Beise 1999: 4). Well-known examples include the United States as a lead market for the Internet, Japan as a lead market for fax machines, or Finland as a lead market for mobile phones. Empirically, lead markets are characterized by high percapita income, demanding, innovative buyers, high-quality standards and pressure for change (see also F. Meyer-Krahmer 2000).

Lead markets for environmental technologies, however, are characterised by additional factors. They are typically not only stimulated by higher environmental preferences of consumers in that country, but also by special promotional measures or by political intervention in the market. A lead market for environmental innovations relates to global environmental needs and is 
-due to market failures- strongly dependent on government support, sometimes also on support from NGOs such as Greenpeace or the media.

Here again the role of the highly developed nation state and of pioneer countries is crucial: The global economy and its multinational enterprises are still in need of locations where the risky take-off of a new environmental technology finds public support and innovative buyers who are willing to pay a higher price and accept the teething problems of that technology, before it becomes cheap and effective enough to succeed in global markets. The regulators in Denmark and Germany created favourable market conditions and the customers of electricity in both countries were willing to bear the high price for wind-power technology until it became competitive and profitable in the global market.

\section{8) Environmental policy innovation, as well as regression, originate primarily at the national level}

In an expert inquiry in twenty different countries, we asked the participants: 'What are the main restrictive sectors in environmental protection?' The answer was: First, the energy sector; second, road congestion; third, agriculture; fourth, the construction sector (Jänicke \& Weidner 1997). These are actually sectors that are not under tough global competition; one could even say that the contrary is true (agriculture, the power industry, and the construction industry strongly depend on public or regulated demand). Quite often it is again the nation state that resists international regulation: countries such as the US, Japan, the UK or, more recently, Denmark are examples of the double option of either being an innovator or a laggard in environmental policy.

\section{9) The nation state will remain the 'local hero', not least in the field of environmental protection}

There is no functional equivalent to national governments as highly visible, legitimised and competent territorial actors and protectors (Willke 1992). To whom could we address our complaints on environmental violations or issues such as BSE if not to this actor? Governments, on the other hand, have no exit option. They need both a material and a political basis. They do not 
respond to economic pressure alone. The legitimation they need necessitates a broader orientation. The environment is an aspect that cannot be ignored. Therefore, national governments try to seek compromises between the economy and the ecology. The answer is technology. Insofar as technology can provide solutions to environmental problems (in many fields we need more far-reaching 'structural' solutions), the potential of national policy action is stronger than generally assumed. This solution, however, is essentially restricted not only by the general availibility of technology, but also to the more advanced countries.

\section{0) Global environmental governance strongly depends on both the competence and creativity of national governments and the interna- tional system as a complex mechanism of policy diffusion and co-or- dination}

Of course, this ('horizontal') view on the role of national governments is no alternative to the ('vertical') view on international institutions. The more interesting question is whether international regulation or the competitive role of pioneer countries represents the main catalyst for global environmental policy development. At the Johannesburg Summit, the European Union (strongly influenced by the German government) has for the first time gone beyond the minimalist global consensus by stressing its pioneer role. Together with a large group of countries, it is committed to following an ambitious policy in support of renewable energies.

This paper has underlined the role of the pioneers of innovation and diffusion. We need a lot more research on the role of different national policies, as well as on the mechanism of political competition in the global arena to offer a satisfactory answer to the question. But even if the competitive pressure (both in policy and technology) exerted by pioneers in environmental policy would prove to be the strongest driving force, international institutions would still play an important role as policy arenas and as agents of diffusion. 


\section{Two Approaches to Global Environmental Policy:}

- 'Governance by international regulations': Focus on international institutions, negotiations and regulations and their effects on national policies (e.g. Kyoto protocol)

- Main perspective: vertical processes, bottom-up, top down

- International consensus on a low level

- 'Governance by diffusion': Influence of pioneer countries in terms of the diffusion of environmental policy innovations (e.g. green tax reform) - Main perspective: horizontal processes, best practice, international transfer mechanisms, competitive mechanisms (benchmarking, markets) - Pioneer policy on a high level

Jänicke / FFU 2000

\section{Conclusions}

This short presentation should not be misconstrued as painting an optimistic picture of globalisation. In general, we are not very successful in the field of environmental protection. Global economic development increases both the level of environmental pressure (e.g. in the field of transportation) and the capacity to react to environmental problems. Environmental policy may never win the race between these two tendencies. However, the question is whether globalisation is the main problem.

In sum, neither the increased importance of global markets nor the globalisation of political governance have weakened the role of national governments. '...[T] he economic dimensions of globalisation have had little, if any, impact on lowering national regulatory standards, while the social and political dimensions of globalisation have, on balance, contributed to the strengthening of national regulatory standards' (David Vogel 2001). 'States in concert' have expanded and co-ordinated their regulatory powers. And it is only the state, the guarantor of diverse societal interests, that has the competence, the resources, the power and the legitimacy 'to regulate the actions of disparate actors who, in their pursuit of individual gain, might otherwise destroy shared environmental resources' (Raustiala 1997).

One important reservation, however, needs to be put forth: It is the highly 
developed nation state which has preserved or even increased its capacity in the context of globalisation. The situation in the less developed countries is quite different.

Keeping this in mind, we could draw two political and normative conclusions from the ten statements mentioned above:

First, there is a remarkable potential in the advanced OECD countries to promote change through the adoption of a pioneering policy, the stimulation of international competition and the diffusion of best practice. This may sometimes be more helpful than relying only on weak and/or on weakly-implemented treaties such as the Kyoto protocol.

Second, this potential of the highly advanced countries may be seen as a moral argument to assume a higher responsibility for global environmental development. The advanced nations cannot hide behind the fictitious monster of globalisation, seemingly legitimising any kind of inactivity. On the contrary, it is their obligation to provide the world with better 'demonstration effects', with a better model of production and consumption, overcoming the resource and environment intensive model of the past.

\section{Bibliography}

Andersen, M. S. \& Liefferink, D. (eds.) (1997). European Environmental Policy. Manchester: The Pioneers.

Ashford, N. A. et al. (1979). Environment, Health, Safety Regulation, and

Technological Innovation. In Hill, C.T./Utterback, J. (eds.) Technological Innovation for a Dynamic Economy. Cambridge.

Beise, M. (2001). Lead Markets. Country Specific Success Factors of the Global Diffusion of Innovations. Heidelberg/New York: Physica Verlag.

Beise, M. (1999). Lead Markets and the International Allocation of $R \& D$. Paper Prepared for the 5. ASEAT Conference 'Demand, Markets, Users and Innovation: Sociological and Economic Approaches', Sept. 14-16, Manchester.

Bennett, C.J. (1991). 'What is Policy Convergence and What Causes it?' British Journal of Political Science, 21: 215-233.

Bernauer, T. (2000). Staaten im Weltmarkt. Zur Handlungsfähigkeit von Staaten trotz Wirtschaftlicher Globalisierung. Opladen: Leske+Budrich.

Busch, P.-O., Jörgens, H. (2002). Globale Diffusionsmuster Umweltpolitischer Innovationen. Forschungsstelle für Umweltpolitik, FFU Report. Berlin. 
Cameron, D. R. (1978). 'The Expansion of the Public Economy: A Comparative Analysis'. American Political Science Review, 72, 4.

Drezner, D. W. (2001). 'Globalization and Policy Convergence'. The International Studies Review, 3, 1: 53-78.

Eliste, P. \& Fredriksson, P.G. (1998). Does Open Trade Result in a Race to the Bottom? Cross Country Evidence. Unpublished MS (World Bank).

Foljanty-Jost, G. (1997). Die Bedeutung Japans für die Vergleichende Umweltpolitikforschung - Vom Modell zum Auslaufmodell? In Mez, L. \& Weidner, H. (eds.) Umweltpolitik und Staatsversagen. Perspektiven und Grenzen der Umweltpolitikanalyse. Berlin: Edition Sigma.

Faucheux, S. (2000). Environmental Policy and Technological Change. Towards Deliberative Governance. In Hemmelskamp, J./Rennings, K. \& Leone, F. (eds.) Innovation-Oriented Environmental Regulation. Theoretocal Approaches and Empirical Analysis. Heidelberg. New York: Physica.

Garrett, G. (1998). Partisan Politics in the Global Economy. Cambridge: Cambridge University Press.

Hettige, H., Huq, M., Pargal, S. \& Wheeler, D. (1996). 'Determinants of Pollution Abatement in Developing Countries: Evidence from South and South East Asia'. World Development, 24, 12: 1891-1904.

Jaffe, B., Peterson, S. R., Portney, P. R. \& Stavins, R. (1995). 'Environmental Regulation and Competitiveness of U.S. Manufacturing: What Does Evidence Tell Us?' Journal of Economic Literature, 33, 1: 136-63.

Jänicke, M., Binder, M., \& Mönch, H. (1997). '«Dirty Industries»: Patterns of Change in Industrial Countries'. Environmental and Resource Economics, 9: 467-491.

Jänicke, M. \& Jacob, K. (2001). 'Global Environmental Change and the Nation State: Lead Markets for Environmental Innovations'. Paper Presented at the Conference 'Global Environmental Change and the Nation State'. Berlin 7-8 December.

Jänicke, M. \& Weidner, H. (eds.) (in coll. with Jörgens Helge) (1997). National Environmental Policies: A Comparative Study of Capacity-Building. Berlin u.a.: Springer.

Kern, K., Jörgens, H. \& Jänicke, M. (2001). The Diffusion of Environmental Policy Innovations. Wissenschaftszentrum Berlin, FS II 01-302.

Meyer-Krahmer, F. (1999). Was Bedeutet Globalisierung für Aufgaben und Handlungsspielräume Nationaler Innovationspolitiken? In Grimmer, K., 
Kuhlmann, St. \& Meyer-Krahmer, F. (eds.) Innovationspolitik in Globalisierten Arenen. Opladen: Leske Budrich.

Ministry of the Environment (1995). Korea's Green Vision 21. Kwacheon: Ministry of Environment.

Porter, M. E. (1990). The Competitive Advantage of Nations. New York: The Free Press.

Porter, M. E. \& Van der Linde, C. (1995). 'Green and Competitive: Ending the Stalemate'. Harvard Business Review, 9/10: 120-134.

Raustiala, K. (1997). 'States, NGOs, and International Environmental Institutions'. International Studies Quarterly, 41: 719-740.

Rose, R. (1993). Lesson-Drawing in Public Policy. A Guide to Learning Across Time and Space. Chatham/NJ: Chatham House.

Scharpf, F. W. (1998). Die Problemlösungsfähigkeit der Mehrebenenpolitik in Europa. In Kohler-Koch, B. (ed.) Regieren in Entgrenzten Räumen. Sonderheft 29 der PVS. Opladen: Westdeutscher Verlag.

Sturm, A., Wackernagel, M. \& Müller, K. (2000). The Winners and Losers in Global Competition. Why Eco-Efficiency Reinforces Competitiveness: A Study of 44 Nations. Chur/Zürich: Verlag Rüegger.

Vogel, D. (2001). 'Is There a Race to the Bottom? The Impact of Globalization on National Regulatory Policies'. The Tocqueville Review/La Revue Tocqueville, XXII, 1.

Wallace, D. (1995). Environmental Policy and Industrial Innovation. Strategies in Europe, the USA and Japan. London: Earthscan.

Weidner, H. \& Jänicke, M. (eds.) (2002). Capacity Building in National Environmental Policy. A Comparative Study of 17 Countries. Berlin u.a.: Springer.

Wheeler, D. (2001). 'Racing to the Bottom? Foreign Investment and Air Pollution in Developing Countries'. Journal of Environment \& Development, 10, 3: 225- 245. 